\title{
Chemical Composition, FTIR Studies and Antibacterial Activity of Passiflora edulis f. edulis (Fruit)
}

\author{
Humaira Rizwana ${ }^{1 *}$ (D) Fatimah Al Otibi ${ }^{1}$ (D) and Nouf Al-malki² \\ ${ }^{1}$ Department of Botany and Microbiology, College of Science, King Saud University, Riyadh, Saudi Arabia. \\ ${ }^{2}$ King Fahd Specialist Hospital-Dammam, P. O. Box 15215, Saudi Arabia.
}

\begin{abstract}
Because of the strong interest in the use of bio-products as alternatives to chemically derived antibiotics or antimicrobial agents, passion fruits extracts were evaluated for their antibacterial activity and chemical composition. Various solvent extracts of $P$. edulis were screened for their antibacterial activity by Agar well diffusion technique against an array of pathogenic bacteria (Gram positive and negative). Macro dilution technique was used to determine the Minimum inhibitory concentration of the potent extracts. Bacterial strain showing significant inhibition was further subjected to scanning electron microcopy (SEM) and the morphological changes induced by extracts were noted. Chemical composition of extracts showing strong antibacterial activity was determined by GC-MS and FTIR analysis. Extracts of Passion fruit (pulp with seeds) show significant inhibitory effects against test isolates but in a variable manner. Amongst all the test isolates Bacillus subtilis showed maximum inhibition followed by $E$. coli and $P$. aeruginosa. Ethyl acetate extracts had the least activity against the tested microorganisms. Gas chromatography-mass spectrometry of ethanol extracts showed the presence of important chemicals, such as Tetracosamethyl-cyclododecasiloxane; Dodecanoic acid, 10-methyl-, methyl ester cyclosiloxane, hexadecamethyl; 3-isopropoxy-1,1,1,7,7,7-hexamethyl-3,5,5-tris (trimethylsiloxy)tetrasil; 9-hexadecenoic acid, 9-octadecenyl ester, (Z,Z)- Fourier transform infrared studies revealed important functional groups which included phenols, esters, flavonoids, aromatic compounds, and alcohols. Significant antibacterial activity of the extracts could be attributed to phenolic compounds, esters and other chemical components identified in ethanolic extracts. Scanning electron micrographs of $B$. subtilis treated with ethanol extracts showed distorted shapes, rough and corrugated cell margins, and aggregations of cells. Our data depict the significant antimicrobial activity of extracts against Gram positive bacteria while the Gram negative bacteria exhibited weak inhibition by all the extracts. Based on our findings, passion fruits can be used in preparations of antimicrobial formulations against Gram positive microorganisms especially $B$. subtilis.

Keywords: Passion fruit, pulp, Rind, scanning electron microscopy, Gas chromatography-mass spectrometry, Fourier transform infrared.
\end{abstract}

*Correspondence: hrizwana@ksu.edu.sa

(Received: 02 November 2019; accepted: 22 December 2019)

Citation: Humaira Rizwana, Fatimah Al Otibi and Nouf Al-malki, Chemical composition, FTIR Studies and Antibacterial Activity of Passiflora edulis f. edulis (Fruit), J Pure Appl Microbiol., 2019; 13(4):2489-2498. https://doi.org/10.22207/JPAM.13.4.64

(C) The Author(s) 2019. Open Access. This article is distributed under the terms of the Creative Commons Attribution 4.0 International License which permits unrestricted use, sharing, distribution, and reproduction in any medium, provided you give appropriate credit to the original author(s) and the source, provide a link to the Creative Commons license, and indicate if changes were made. 


\section{INTRODUCTION}

Plants serve as one the largest natural resource reservoirs. These resources have been explored for the presence of potent chemical compounds, applicable in the pharmaceutical, cosmetic, and nutraceutical industries. Yet, from a huge estimate of 250,000-500,000 plant species on Earth, only a very small fraction (1-10\%) have been explored for compounds that may serve as antimicrobials ${ }^{1,2}$. In fact, medicinal plants have always occupied a vital place in our culture since time immemorial. Some Asian populations (80\%) still depend on traditional medicines derived from plants ${ }^{3}$. Moreover, recent research has discovered chemicals from plants, which possess promising antimicrobial properties that can serve as novel therapeutic compounds. The rise in antimicrobial resistance, has forced mankind to explore new alternatives with fewer irreversible side effects. The best solution to the menace of resistant microbial strains is herbal constituents that are easily available and affordable. Hence, this need has prompted us and various researchers worldwide to investigate plants and their products for their antimicrobial activity against resistant strains of pathogenic bacteria and fungi.

Passion fruit is an exotic tropical and subtropical fruit, belonging to the family Passifloraceae with an estimate of 500 species. Amongst the species, $P$. edulis, $P$. ligularis, and $P$. quadrangularis are chiefly cultivated for their edible fruit, economic importance, ornamental purpose, and medicinal properties ${ }^{4}$. P. edulis Sims is a perennial vine and growing at higher altitudes. It has two forms; the yellow fruit called the Passiflora edulis f. flavicarpa Deg. and the purple form referred to as Passiflora edulis $f$. edulis. The purple fruit is a native of Brazil, it is smaller in size with a strong aroma and is more acidic than the yellow type. Passion fruits are rich in vitamin C, A, niacin, and fiber. All the plant parts have medicinal properties and are used in various forms of herbal medicine. Dried flower and fruits are used to treat constipation, gastric ailments, as a digestive stimulant and treating gastric cancer ${ }^{5}$ Boiled leaves are used to treat hypertension and chronic dysentery in some parts of India ${ }^{6}$.

Passion fruit and its peel have shown positive results in treating asthma, high blood pressure, menopausal symptoms, and osteoarthritis, and act as an excellent antiinflammatory, anti-helminthic, sedative, and diuretic ${ }^{7-11}$.

For a few years, passion fruit has drawn the attention of many researchers because of its wide chemical composition. The purple fruit is not well studied for its antimicrobial properties and its chemical composition; hence, in the present research, we explore the antimicrobial efficacy of fruit pulp and peel extracts. Further, scanning electron microscopy of severely affected microbial strains will be conducted to understand the potency of extracts on cell morphology.

\section{MATERIALS AND METHODS}

\section{Plant material: Passion fruits}

Fresh, disease- and injury-free fruits of Passiflora edulisf. edulis Sims (purple variety) were collected from a local market in Riyadh (Fig. 1). The fruits were washed with tap water followed by distilled water. Fruits were then cut, and the pulp was separated from the peel. Fruit pulp with the seeds and peels were freeze dried separately, and ground into fine powder with a mixer grinder. The powder was subjected to extraction.

Preparation of extracts

Pulp and powdered peels (20 g) were subjected to extraction with ethanol, methanol, acetone, and ethyl acetate $(100 \mathrm{ml})$. Extracts were placed on a rotator shaker at $180 \mathrm{rpm}$ for $72 \mathrm{~h}$, after which they were filtered using a Whatman filter paper (No. 1). The filtrates were evaporated in a vacuum evaporator. The extracts were reconstituted in mother solvents and used for antibacterial and antifungal assays.

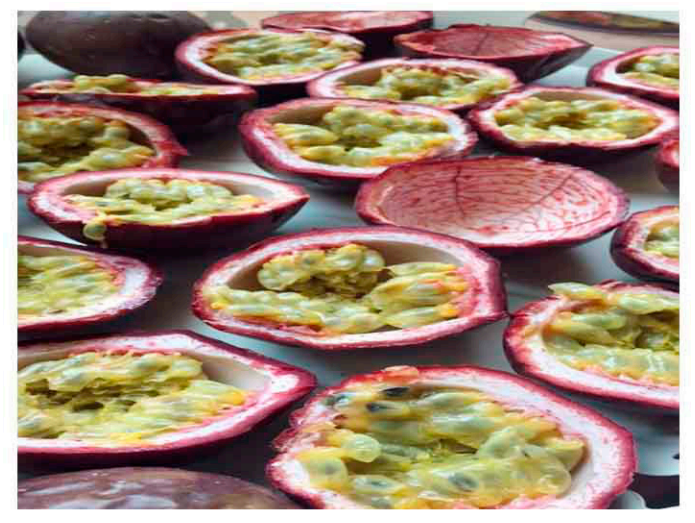

Fig. 1. Passion fruit (Passiflora edulis f. edulis) 


\section{Microbial isolates}

Passion fruit extracts were tested against selected human pathogenic microorganisms. Bacterial isolates included Gram-negative and gram-positive bacteria, namely Staphylococcus aureus ATCC 25923, Bacillus subtilis ATCC 6633, Escherichia coli ATCC 25966, Pseudomonas aeruginosa ATCC 27853, Enterococcus faecalis ATCC 29212, and Klebsiella pneumonia (hospital isolate). Fungal isolate screened was Candida albicans ATCC 60193. The tested microorganisms were provided by King Khalid Hospital, RiyadhSaudi Arabia. Microbial isolates were pre-cultured on nutrient agar.

\section{Antibacterial assay}

Antibacterial activities of plant extracts were tested using the agar well diffusion technique ${ }^{12}$ with slight modifications. The culture plates were prepared by pouring $20 \mathrm{ml}$ of Mueller Hinton (MH) agar medium into sterile Petri dishes. The inoculum suspension of $0.5 \mathrm{McFarland}$ was prepared for all bacterial isolates to be tested and $200 \mu \mathrm{l}$ of this suspension was spread uniformly over the agar medium using sterile cotton swabs. With the help of a sterile cork borer of $6 \mathrm{~mm}$ diameter, wells were made equidistantly on the agar surface to be further loaded with $100 \mu$ of solvent extracts. Following loading of the extracts, plates were incubated for $24 \mathrm{~h}$ at $37^{\circ} \mathrm{C}$. The inhibitory activity of these extracts was recorded by measuring the diameter of the inhibition zone $(\mathrm{mm})$ formed around the well. Tetracycline $(30 \mu \mathrm{g})$ and ampicillin $(10 \mu \mathrm{g})$ discs were used for antibiotic sensitivity assays and the largest zone shown by the respective antibiotic was tabulated. Mother solvent served as a negative control, whereas the antibiotic disc was the positive control. Candida albicans was tested for its antifungal activity with Mueller Hinton agar along with bacterial isolates. Minimum inhibitory concentration of extracts against bacteria

Minimum Inhibitory Concentration (MIC) for bacteria and yeast was determined by Broth tube dilution method with slight modification ${ }^{13,14}$. A double dilution of extracts $(0.125 \mathrm{mg} / \mathrm{ml}-128$ $\mathrm{mg} / \mathrm{ml}$ ) was prepared using Mueller Hinton Broth. Equal volumes of extract and broth were added to a sterile test tube followed by a fixed volume of Microbial cell suspension containing $5 \times 105$ CFU/ $\mathrm{ml}$ of cells. This concoction was incubated for 24

Table 1. Antibacterial activity of fruit pulp (with seeds) and zones of inhibition ( $\mathrm{mm}$ )

\begin{tabular}{lccccc}
\hline \multicolumn{1}{c}{ Organism } & Acetone & Methanol & Ethanol & $\begin{array}{c}\text { Ethyl } \\
\text { acetate }\end{array}$ & Antibiotic \\
\hline Staphylococcus aureus & $15.00 \pm 0.81$ & $14.66 \pm 0.94$ & $17.00 \pm 1.63$ & $0.00 \pm 0.00$ & $29 \mathrm{~mm}(\mathrm{~T})$ \\
Bacillus subtilis & $17.33 \pm 0.94$ & $16.00 \pm 0.00$ & $24.66 \pm 0.47$ & $10.33 \pm 0.47$ & $30 \mathrm{~mm}(\mathrm{~T})$ \\
Escherichia coli & $14.00 \pm 0.81$ & $13.00 \pm 1.41$ & $19.00 \pm 0.81$ & $0.00 \pm 0.00$ & $32 \mathrm{~mm}(\mathrm{~T})$ \\
Pseudomonas aeruginosa & $18.66 \pm 0.47$ & $10.00 \pm 0.81$ & $18.33 \pm 1.24$ & $9.00 \pm 0.00$ & $30 \mathrm{~mm}(\mathrm{~A})$ \\
Klebsiella pneumoniae & $11.00 \pm 0.81$ & $9.00 \pm 0.47$ & $10.00 \pm 0.00$ & $9.00 \pm 0.47$ & $10 \mathrm{~mm}(\mathrm{~A})$ \\
Candida albicans & $17.00 \pm 0.00$ & $15.00 \pm 0.81$ & $17.33 \pm 0.94$ & $0.00 \pm 0.00$ & $19 \mathrm{~mm}(\mathrm{~F})$ \\
\hline
\end{tabular}

T-Tetracycline (30 $\mu \mathrm{g})$, F-Fluconazole $(25 \mu \mathrm{g})$, A- Ampicillin $40 \mu \mathrm{g} / \mathrm{ml}$. Values are means of three replicates and \pm SD

Table 2. Antibacterial activity of fruit peel and zones of inhibition $(\mathrm{mm})$

\begin{tabular}{lccccc}
\hline \multicolumn{1}{c}{ Organism } & Acetone & Methanol & Ethanol & $\begin{array}{c}\text { Ethyl } \\
\text { acetate }\end{array}$ & Antibiotic \\
\hline Staphylococcus aureus & $8.00 \pm 0.00$ & $10.33 \pm 0.94$ & $10.00 \pm 0.81$ & $0.00 \pm 0.00$ & $29 \mathrm{~mm}(\mathrm{~T})$ \\
Bacillus subtilis & $11.66 \pm 0.47$ & $0.00 \pm 0.00$ & $0.00 \pm 0.00$ & $9.33 \pm 0.00$ & $30 \mathrm{~mm}(\mathrm{~T})$ \\
Escherichia coli & $0.00 \pm 0.00$ & $10.00 \pm 1.41$ & $12.33 \pm 0.47$ & $0.00 \pm 0.00$ & $32 \mathrm{~mm}(\mathrm{~T})$ \\
Pseudomonas aeruginosa & $0.00 \pm 0.00$ & $9.00 \pm 0.00$ & $9.00 \pm 0.81$ & $0.00 \pm 0.00$ & $30 \mathrm{~mm}(\mathrm{~T})$ \\
Klebsiella pneumoniae & $0.00 \pm 0.00$ & $10.00 \pm 1.00$ & $0.00 \pm 0.00$ & $11.33 \pm 0.94$ & $24 \mathrm{~mm}(\mathrm{~T})$ \\
Candida albicans & $8.33 \pm 0.47$ & $0.00 \pm 0.00$ & $15.00 \pm 0.81$ & $0.00 \pm 0.00$ & $18 \mathrm{~mm}(\mathrm{~F})$ \\
\hline
\end{tabular}

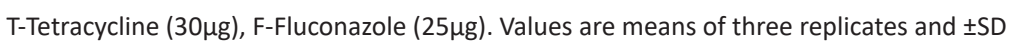


$\mathrm{h}$ at $37^{\circ} \mathrm{C}$. The lowest concentration that did not show any visible growth was regarded as its MIC. The experiment was performed in triplicates and their mean values were noted.

Gas chromatography-mass spectrometry (GC-MS) analysis

Ethanol extract was subjected to GC-MS analysis. GC-MS analysis was carried out on Clarus 500 Mass spectrometer and gas chromatography. Different parameters involved in the operation of the Clarus $500 \mathrm{MS}$ were standardized as follows: mass spectra were taken at $70 \mathrm{eV}$; acquisition mode - scan 40-550 amu; ion source temperature $230^{\circ} \mathrm{C}$; inlet line temperature $200^{\circ} \mathrm{C}$; solvent delay time $5 \mathrm{~min}$. Gas chromatography used in the analysis employed a fused silica column [100\% dimethyl poly siloxane, $30 \mathrm{~nm}$ ' $0.25 \mathrm{~nm}$ ID ' $1 \mu \mathrm{m}$ df]. The column was packed with Elite-1. Helium was used as the carrier gas $(1 \mathrm{ml} / \mathrm{min})$. The extract $(2 \mu l)$ was injected into the instrument. The oven temperature program was $2 \mathrm{~min}$ at $45^{\circ} \mathrm{C}, 1.5^{\circ} \mathrm{C} /$ min to $100^{\circ} \mathrm{C}$, and $2^{\circ} \mathrm{C} / \mathrm{min}$ to $200^{\circ} \mathrm{C}$ during the GC extraction process; the split ratio was 25:1. The injector temperature was $250^{\circ} \mathrm{C}$. The GC run time was $90 \mathrm{~min}$. The identification of the phytocompounds and interpretation of the mass spectrum were performed with the aid of the standards database of the NIST libraries.

Fourier Transform Infrared (FTIR) Fingerprint Analysis
Fourier transform infrared (FTIR- Perkin Elmer 2000) spectrophotometer was used to identify the functional groups present in ethanol and acetone extracts. The extracts were centrifuged, filtered, diluted (1:10), and subjected to analysis in the scan range 400 to $4000 \mathrm{~cm}^{-1}$.

Bruker OPUS software was used to analyze the spectrum.

\section{Scanning electron microscopy (SEM)}

The SEM was performed as previously reported, with slight modification ${ }^{14} \mathrm{~B}$. subtilis cell suspension at its MIC $(0.25 \mathrm{mg} / \mathrm{ml})$ treated with ethanol pulp extract was selected for the SEM analysis. The bacterial cell suspension was subjected to centrifugation (8,000 ' $g$ for $10 \mathrm{~min}$ ). Centrifuged cells were fixed by immersing in $2.5 \%$ glutaraldehyde and then washed with $0.1 \mathrm{~mol} / \mathrm{L}$ tris-acetate buffer ( $\mathrm{pH}$ 7.2). Dehydrated samples were freeze-dried and observed by SEM (JEOL, Japan). Cells grown in an $\mathrm{MH}$ tube with no extract were used as a control.

\section{RESULTS}

The anti-microbial results of the extracts in this study are recorded in Tables 1 and 2. Pulp (with seeds) extracts were more effective than that of the peel. All the tested organisms showed variable sensitivity towards the extracts. However, we noted that the highest antibacterial activity was observed with the ethanol extract, particularly

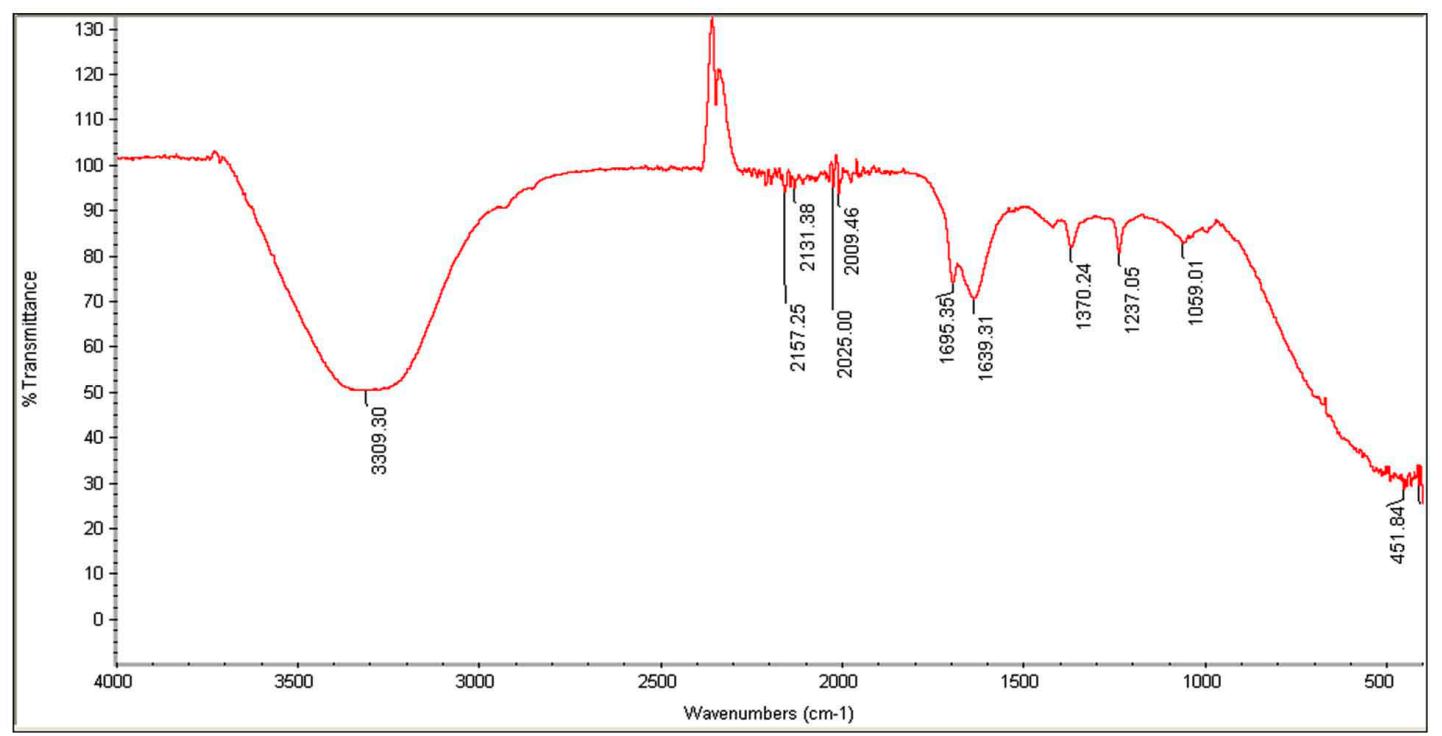

Fig. 2. FTIR spectrum for passion fruit with pulp and seeds (acetone extracts) 
against Bacillus subtilis (24 mm), Escherichia coli $(19 \mathrm{~mm})$ and Pseudomonas aeruginosa (18 $\mathrm{mm})$, followed by the acetone extract against $P$. aeruginosa (18 $\mathrm{mm}$ ) and Bacillus subtilis (17 $\mathrm{mm}$ ). Ethyl acetate had negligible effects on all the test organisms. On the other hand, Candida albicans was susceptible to both acetone and ethanolic extracts (18 $\mathrm{mm}$ and $17 \mathrm{~mm}$ ) compared to the other organic extracts (Table 1). Peel extracts, however, did not exhibit significant antimicrobial activity, except for C. albicans which showed a maximum zone of inhibition $(15 \mathrm{~mm})$ with ethanol extracts.

\section{Minimum inhibitory concentration}

The MIC required to completely arrest the growth of test isolates with pulp extracts ranged between $0.25-128 \mathrm{mg}^{-1} \mathrm{ml}^{-1}$, while for peel it was between 2 - $128 \mathrm{mg} / \mathrm{ml}^{-1}$. Amongst all the pulp extracts, ethanol, methanol and acetone extracts inhibited Bacillus subtilis with the least MIC of 0.25 $\mathrm{mg} / \mathrm{ml}^{-1}$, and $0.5 \mathrm{mg} / \mathrm{ml}^{-1}$ each . Candida albicans was inhibited at a MIC of $0.5 \mathrm{mg} / \mathrm{ml}$. with ethanol pulp extracts. However, all the peel extracts inhibited the test isolates with a high MIC but in a variable manner. (Table 3, 4)

\section{GC-MS}

GC-MS of ethanol extracts showed important chemicals, including tetracosamethylcyclododecasiloxane, dodecanoic acid, 10-methyl-, methyl ester cyclosiloxane, hexadecamethyl; 3-isopropoxy-1,1,1,7,7,7-hexamethyl-3,5,5-tris (trimethylsiloxy)tetrasil; 9-hexadecenoic acid, 9-octadecenyl ester, (Z,Z)-, cyclononasiloxane, and octadecamethyl; 9,12-tetradecadien-1-ol, (Z,E). (Table 5)

Table 3. Minimum inhibitory concentration of passion fruit pulp with seeds $\left(\mathrm{mg} / \mathrm{ml}^{-1}\right)$

\begin{tabular}{lcccc}
\hline Organism & Acetone & Methanol & Ethanol & $\begin{array}{c}\text { Ethyl } \\
\text { acetate }\end{array}$ \\
\hline Staphylococcus aureus & 1 & 4 & 0.5 & $\mathrm{NI}$ \\
Bacillus subtilis & 0.5 & 0.5 & 0.25 & 8 \\
Escherichia coli & 4 & 32 & 1 & $\mathrm{NI}$ \\
Pseudomonas aeruginosa & 0.5 & 16 & 0.5 & 16 \\
Klebsiella pneumoniae & 32 & 32 & 32 & 64 \\
Candida albicans & 1 & 2 & 0.5 & $\mathrm{NI}$ \\
\hline
\end{tabular}

Each value shown in the above table is a mean of three replicates and \pm SD. NI-not inhibited.

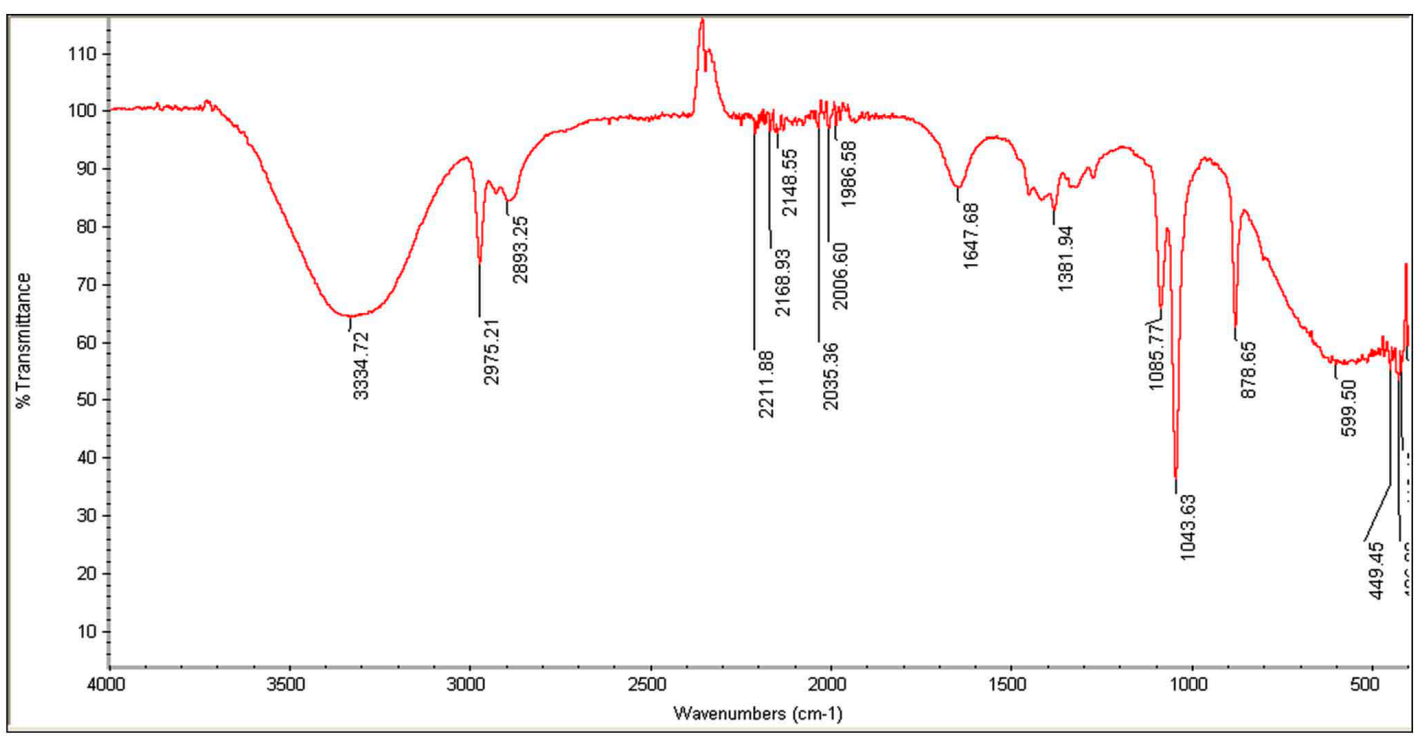

Fig. 3. FTIR spectrum of passion fruit with pulp and seeds (ethanol extract) 


\section{FTIR analyses}

The FTIR spectra of the organic extracts ethanol and acetone, in particular, revealed the presence of the following important functional groups: alcohols, alkanes, esters, aromatic compounds, phenols, carbonyl compounds, and ketones (Tables 6, 7). Peaks at 3309, 3334, and 1370 are caused by the $-\mathrm{OH}$ stretch of alcohols and phenols. Similarly, the series of peaks at 2970, 2930 , and 2869 were caused by the symmetric and asymmetric stretches of $-\mathrm{CH}$, whereas the peaks between 2006-2211 were attributed to stretches,

Table 4. Minimum inhibitory concentration of passion fruit peel extracts $\left(\mathrm{mg} / \mathrm{ml}^{-1}\right)$

\begin{tabular}{lcccc}
\hline Organism & Acetone & Methanol & Ethanol & $\begin{array}{c}\text { Ethyl } \\
\text { acetate }\end{array}$ \\
\hline Staphylococcus aureus & 128 & 16 & 16 & $\mathrm{NI}$ \\
Bacillus subtilis & 8 & $\mathrm{NI}$ & $\mathrm{NI}$ & 64 \\
Escherichia coli & $\mathrm{NI}$ & 4 & 4 & $\mathrm{NI}$ \\
Pseudomonas aeruginosa & $\mathrm{NI}$ & 8 & 4 & $\mathrm{NI}$ \\
Klebsiella pneumoniae & $\mathrm{NI}$ & 16 & $\mathrm{NI}$ & 32 \\
Candida albicans & 64 & $\mathrm{NI}$ & 2 & $\mathrm{NI}$
\end{tabular}

Each value shown in the above table is a mean of three replicates and \pm SD. NI-not inhibited.

Table 5. Chemical compounds identified from the GC-MS analysis of the ethanol extract of passion fruit pulp with seeds

\begin{tabular}{llll}
\hline S.no & \multicolumn{1}{c}{ Name of the compound } & $\begin{array}{c}\text { Molecular } \\
\text { formula }\end{array}$ & $\begin{array}{c}\text { Molecular } \\
\text { weight }\end{array}$ \\
\hline 1 & Tetracosamethyl-cyclododecasiloxane & $\mathrm{C}_{24} \mathrm{H}_{72} \mathrm{O}_{12} \mathrm{Si}_{12}$ & 889 \\
2 & Cyclooctasiloxane, Hexadecamethyl & $\mathrm{C}_{16} \mathrm{H}_{48} \mathrm{O}_{8}$ & 592 \\
3 & Dodecanoic acid, 10-methyl-, methyl ester & $\mathrm{C}_{14} \mathrm{H}_{28} \mathrm{O}_{2}$ & 228. \\
4 & 3-Isopropoxy-1,1,1,7,7,7-hexamethyl-3,5,5- & $\mathrm{C}_{18} \mathrm{H}_{52} \mathrm{O}_{7} \mathrm{Si}_{7}$ & 577 \\
& tris(trimethylsiloxy)tetrasil & $\mathrm{C}_{18} \mathrm{H}_{54} \mathrm{O}_{9} \mathrm{Si}_{9}$ & 667 \\
5 & Cyclononasiloxane, Octadecamethyl & $\mathrm{C}_{34} \mathrm{H}_{64} \mathrm{O}_{2}$ & 504. \\
6 & 9-Hexadecenoic acid, 9-octadecenyl ester, (Z,Z)- & $\mathrm{C}_{14} \mathrm{H}_{26} \mathrm{O}^{2}$ & 210 \\
\hline
\end{tabular}

Table 6. IR Spectrum for passion fruit with pulp and seeds: Acetone extracts

\begin{tabular}{|c|c|c|c|}
\hline $\begin{array}{c}\text { Peak values } \\
\text { (frequency, } \mathrm{cm}^{-1} \text { ) }\end{array}$ & $\begin{array}{l}\text { Functional } \\
\text { group }\end{array}$ & $\begin{array}{c}\text { Peak values } \\
\text { (frequency, } \mathrm{cm}^{-1} \text { ) }\end{array}$ & $\begin{array}{l}\text { Functional } \\
\text { group }\end{array}$ \\
\hline 3309 & $-\mathrm{OH}$ stretch & 3334 & $-\mathrm{OH}$ stretch \\
\hline 2157 & $\mathrm{C} \equiv \mathrm{C}$ stretching & 2975 & $\mathrm{CH}_{2}$ asymmetry stretching \\
\hline 2131 & $\mathrm{C} \equiv \mathrm{C}$ stretch & 2893 & $\mathrm{CH}_{2}$ symmetry stretching \\
\hline 2025 & $\mathrm{C}=\mathrm{C}$ stretch & 2211 & $\mathrm{C}=\mathrm{C}$ stretch \\
\hline 2009 & $\mathrm{C}=\mathrm{C}$ stretch & 2168 & $\mathrm{C}=\mathrm{C}$ stretch \\
\hline 1695 & $\mathrm{C}=\mathrm{C}$ stretch & 2148 & $\mathrm{C}=\mathrm{C}$ stretch \\
\hline 1639 & $\mathrm{C}=\mathrm{C}$ stretch & 2035 & $\mathrm{C}=\mathrm{C}$ stretch \\
\hline 1370 & $-\mathrm{CH}_{3}$ & 2006 & $\mathrm{C}=\mathrm{C}$ stretch \\
\hline 1237 & $\mathrm{C}-\mathrm{O}$ stretches & 1986 & $\mathrm{C}=\mathrm{C}$ bending \\
\hline \multirow[t]{4}{*}{1059} & C-O stretches & 1647 & $\mathrm{C}=\mathrm{C}$ symmetric stretching \\
\hline & & 1381 & $\mathrm{C}-\mathrm{H}$ rocking stretch \\
\hline & & 1085 & C-O stretch \\
\hline & & 1043 & C-O stretch \\
\hline
\end{tabular}

Table 7. IR Spectrum for passion fruit ethanol extract with pulp and seeds 
vibrations, and deformations of $\mathrm{C} \equiv \mathrm{C}$ and $\mathrm{NH}$. The peaks at 1986,1695 , and 1647 were caused by $C=C$ bending and stretching of aromatic. Peaks at 1043, 1085, and 1237, denoting stretching of C-O (Fig. 2 and 3). Antimicrobial activity could be attributed to the important functional groups, such as alcohols, phenols, aromatic compounds, and esters. SEM

Micrographs of ethanol-treated B. subtilis cells show distorted shape, rough and corrugated cell margins. Blebs, protrusions and the aggregation of cells leading to complete damage of cells was also observed. Control cells, which did not receive treatment exhibited well defined complete and regular morphology. (Fig. 4. A-D).
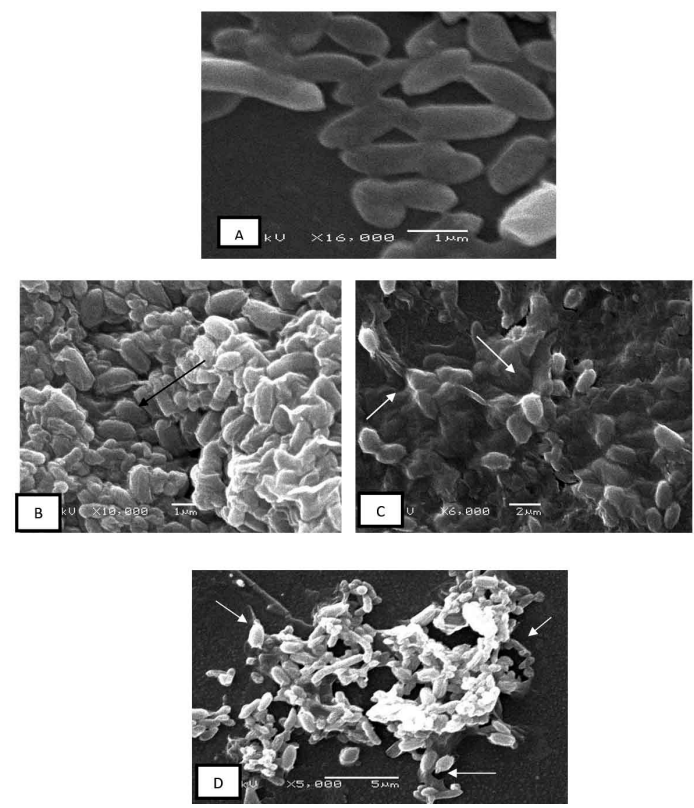

Fig 4. Microphotographs of Bacillus subtilis cells (treated/control) with ethanol extracts of fruit pulp with seeds

Scanning electron microscopy of B. subtilis A-control cells, non-treated cells with well-defined margins $\mathrm{B}$ and $\mathrm{C}-$ Treated cells show clumping and aggregation of cells.

D-Leaked cells with blebs and protrusion, completely distorted and damaged cells can be seen.

\section{DISCUSSION}

The present study showed the significant antibacterial and antifungal activity of passion fruit (pulp) extracts but in a variable manner. Ethanol and acetone extracts were most effective in controlling the growth of test isolates, which could be attributed to the high polarity of solvent, which is excellent in extracting some important phenols and other bioactive compounds. Based on the inhibition zones the antibacterial activity was classified according to Okonko et al., Bacterial isolates were considered sensitive or susceptible if the inhibition zones is $>18 \mathrm{~mm}$; intermediate inhibition if the zone is between $13-17 \mathrm{~mm}$; resistant when the zone is $<13 \mathrm{~mm}^{15}$. It was interesting to note that Gram positive bacteria were more susceptible to extracts than the Gram negative isolates. The strongest inhibition was shown by ethanol (pulp with seeds) extracts against $B$. subtilis with a maximum zone of inhibition (24 mm) and low MIC value $(0.25 \mathrm{mg} /$ $\left.\mathrm{ml}^{-1}\right)$.

Similar to our findings, Kanu et al., recently reported the antimicrobial activity of ethanolic extracts of $P$. edulis var. flavicarpa seeds. Amongst the three microbes screened, $C$. albicans and S. aureus were more susceptible than E. coli, their inhibition zones ranged between $5 \mathrm{~mm}-18$ $\mathrm{mm}^{16}$. Therefore, as revealed by the antibacterial assay, significant inhibition was observed with gram-positive bacteria in comparison to gramnegative. Our findings are in agreement with Kanu et $a l .{ }^{16}$. The differences in the sensitivity were caused by the chemical composition of their cell envelopes, which differed in permeability. The lipopolysaccharide layer present in the outer membrane of Gram negative bacteria is very tough and impermeable to bioactive antimicrobial compounds, while the peptidoglycan layer of Gram positive bacteria is easily permeable. Hence, the resistance shown by Gram negative bacteria in the present study, could be due to restricted entry of antimicrobial compounds through the complex and rigid outer membrane ${ }^{17}$. The poor antimicrobial activity shown by other extracts can be due to the weak concentration of certain bioactive antimicrobial compounds extracted by solvents due to their polarity and also the mode of extract preparation ${ }^{18}$.

In another report Ramaiya et al., screened various extracts from leaves and stems of three species of Passiflora., Passiflora quadrangularis, $P$. maliformis, and $P$. edulis. They reported antibacterial activity of various solvent extracts from all species against 10 bacterial strains, 
amongst them methanolic extracts were the most effective. Furthermore, gram-positive bacteria were more susceptible to extracts than gramnegative bacteria ${ }^{19}$. Yet, in another study, passion fruit co-products and albedo, were screened for their antibacterial activity The MIC for the coproducts ranged between $3.125 \mathrm{mg} / \mathrm{mL}-50 \mathrm{mg} /$ $\mathrm{ml}^{20}$. Onuh et al., reported that aqueous extracts of the peel of Passiflora edulis showed strong inhibition of some fungi, especially Rhizopus stolonifer, Aspergillus niger and Penicillium marneffei. Peel extracts were inhibitory towards $P$. aeruginosa, which is not in agreement with our findings ${ }^{21}$.

The GC-MS of fruit extracts showed some important oxygenated mono and diterpenes, esters, and phenols. Similar to our findings, compounds like tetracosamethyl-cyclododecasiloxane, dodecanoic acid, 10-methyl-, methyl ester; cyclosiloxane, hexadecamethyl; 3-isopropoxy-1,1,1,7,7,7hexamethyl-3,5,5-tris (trimethylsiloxy) tetrasil; 9-hexadecenoic acid, 9-octadecenyl ester, (Z,Z)-, 9,12-tetradecadien-1-ol, (Z,E), cyclononasiloxane, and octadecamethyl have been reported earlier from Camellia oleifera seed cake and stems of Cola nitida $^{22,23}$. Compounds, such as tetracosamethylcyclododecasiloxane, cyclosiloxane, and hexadecamethyl have shown antibacterial, antifungal, and antioxidant properties ${ }^{24-27}$ and 9-hexadecenoic acid and 9-octadecenyl ester possess antimicrobial properties ${ }^{28}$. Yet in another study, the phytochemical screening of $P$. edulis seeds revealed the presence of terpenes, flavonoids, alkaloids, steroids, tannins, and glycosides. The antimicrobial activity of the extract was linked to the presence of terpenes, flavonoids, alkaloids, and other chemical components found in the extract ${ }^{16}$.

The significant antimicrobial activity shown by passion fruit pulp extracts (purple variety) in the present study could be attributed to the presence of important bioactive compounds whose presence was indicated in the IR spectrum. Similar to our findings, Wasagu et al., reported the presence of flavonoids, terpenes, phenols, aromatic compounds, and alkaloids from the fruit extracts of $P$. edulis var flavicarpa (yellow fruits). They further stated that these compounds, which play a crucial role in plant defense against microbes, are also responsible for antibacterial activity $^{29}$. Earlier studies report high amounts of phenols, polyphenols, alkaloids, terpenes and flavonoids from fruit pulp and rind of passion fruit and related their presence to plant defense against microbes and also for antibacterial activity ${ }^{30}$. Further, polyphenols, such as isoorientin, orientin, vitexin, isoschaftoside, and luteolin-6-C-fucoside have been identified from yellow passion fruit pulp and seeds $\mathrm{s}^{20,30,31}$.

In the present study, microphotographs of treated cells show the damaging effects of ethanolic (pulp with seeds) extracts on cell morphology. B. subtilis cells treated with ethanolic extracts at its MIC concentration show, cell protrusions, deformed morphology resulting in clumping of cells, while the control cells (untreated) regular cell morphology. Similar changes in morphology and cell integrity have been reported previously when bacteria were treated with fruit extracts of Punica granatum and Mesua ferrea ${ }^{32,33}$. Earlier studies have shown that terpenes, phenols, and flavonoids play an important role in damaging the cytoplasmic membrane, inhibiting cell wall and cell membrane synthesis, causing perforations by reducing membrane fluidity. They also cause inhibition of nucleic acid synthesis ${ }^{34,36}$. In addition, some flavonoids inhibit ATP synthase, which directly effects energy metabolism ${ }^{37}$. Therefore, these bioactive compounds basically destabilize cell membrane integrity by altering their permeability, causing cell disruption. However, there are no studies to my knowledge that show the effect of Passion fruit extracts on cell morphology, hence comparative study cannot be presented here.

\section{CONCLUSION}

Our data depict the significant antimicrobial activity of ethanol and acetone extracts of fruit pulp of Passiflora edulis. Our study shows, ethanol and acetone as effective solvents in extracting important bioactive compounds. The IR spectrum and GCMS showed the presence of some key functional groups. Presence of these bioactive compounds could be responsible for distorting effects seen on cell morphology of $B$. subtilis. Because, the purple variety of the fruit has not been explored thoroughly for its antimicrobial properties and chemical composition, further fractionation and purification will help identify 
the potential chemical compounds and their mode of action. Because the fruits are easily available, their formulations will be affordable and effective in treating pathogenic infections with fewer side effects.

\section{ACKNOWLEDGEMENTS}

This Research Project was supported by a grant from the financial support from the Researchers Supporting Project number (RSP2019/114),King Saud University,Riyadh,Saudi Arabia. The authors would like to extend sincere appreciation for funding this work.

\section{CONFLICTS OF INTEREST}

The authors declares that there is no conflict of interest.

\section{FUNDING}

This study received grant-in-aid from the Researchers supporting Project number (RSP2019/114),King Saud University,Riyadh,Saudi Arabia.

\section{AUTHORS' CONTRIBUTION}

HR designed the experimental work. NA conducted the experimental work.HR analysed the electron microscopic studies. FA assisted in GCMS and IR analysis. HR wrote the manuscript. FA reviewed the manuscript. All autrs approved the manuscript for publication.

\section{DATA AVAILABILITY}

The data that support the findings of this study are available with the corresponding author

\section{ETHICS STATEMENT}

This article does not contain any studies with human participants or animals performed by any of the authors.

\section{REFERENCES}

1. Borris, R.P. Natural products research: perspectives from a major pharmaceutical company. J. Ethnopharmacol., 1996; 51: 29-38. https://doi.org/10.1016/03788741(95)01347-4

2. Osman, K., Evangelopoulos, D. Basavannacharya C et al. An antibacterial from Hypericum acmosepalum inhibits ATP dependent MurE ligase from Mycobacterium tuberculosis. Intern. J. Antimicrob Agents, 2012; 39: 124-129. https://doi.org/10.1016/j. ijantimicag.2011.09.018

3. Tagboto, S., Townson, S. Antiparasitic properties of medicinal plants and other naturally occurring products. Adv. Parasitol., 2001; 50: 199-295. https:// doi.org/10.1016/S0065-308X(01)50032-9

4. Patil, A.S., Paikrao, H.M. Bioassay guided phytometabolites extraction for screening of potent antimicrobials in Passiflora foetida L. J. App. Pharm. Sci., 2012; 2: 137-142. https://doi.org/10.7324/ JAPS.2012.2927

5. Patel, S.S., Soni, H., Mishra, K., Singhai, A.K. Recent updates on the genus Passiflora: A review. Int. J. Res. Phytochem. Pharmacol., 2011; 1: 1-16.

6. Jamir, T.T., Sharma, H.K., Dolui, A.K. Folklore medicinal plants of Nagaland, India. Fitoterapia, 1999; 70: 395401. https://doi.org/10.1016/S0367-326X(99)00063-5

7. Zibadi, S., Farid, R., Moriguchi, S., et al., Oral administration of purple passion fruit peel extract attenuates blood pressure in female spontaneously hypertensive rats and humans. Nutr. Res., 2007; 27:408416. https://doi.org/10.1016/j.nutres.2007.05.004

8. Johnson, M., Maridass, M., Irudayaraj, V. Preliminary phytochemical and anti-bacterial studies on Passiflora edulis. Ethnobotanical Leaflets., 2008; 12: 425-432.

9. Watson, R.R., Zibadi, S., Rafatpanah, H. et al., Oral administration of purple passion fruit peel extract reduces wheeze and cough and improves shortness of breath in adults with asthma. Nutr. Res., 2008; 28: 166171. https://doi.org/10.1016/j.nutres.2008.01.003

10. Farrid, R., Rezaieyazdi, Z., Mirfeizi, Z. et al., Oral intake of purple passion fruit peel extract reduces pain and stiffens and improves physical function in adult patients with knee osteoarthritis. Nutr. Res., 2010; 30: 601-606. https://doi.org/10.1016/j. nutres.2010.08.010

11. Akanbi, B.O., Bondunrin, O.D., Olayanju, S. Phytochemical screening and antibacterial activity of Passiflora edulis. Hygeia. J. Drugs Med., 2011; 3: 46-49.

12. Valgas, C., Souza Simone, Mde., Smania, E.F.A., Smania, $\mathrm{Jr}$, Artur. Screening methods to determine antibacterial activity of natural products. Braz. J. Microbiol., 2007; 38: 369-380. https://doi.org/10.1590/S151783822007000200034

13. CLSI. Methods for Dilution Antimicrobial Susceptibility Tests for Bacteria that Grow Aerobically. 9th Edn., Clinical and Laboratory Standards Institute,Wayne, PA., USA. 2012.

14. Rizwana, H. In vitro antibacterial and antifungal activity of some oils, chemical analysis and their FTIR studies. Int. J. Agric. Biol., 2018; 20: 14881496.

15. Okonko, O.I., Donbraye-Emmanuel, O.B.,Ljandipe, A., Ogun, A.A.,Adedeji, A.O., Udeze, A.O. Antibiotics sensitivity and resistance patterns of pathogens to nitrofurantoin and nalidixic acid in pregnant women with urinary tract infections in Ibadan, Nigeria. MiddleEast. J. Sci. Res., 2009; 4: 105-109.

16. Kanu, A.M., Agwu, C.O., Chidiebere, U., Ugochi, N.A. Phytochemical screening and antimicrobial activity of ethanoic extract of Passiflora edulis var. flavicarpa seed on selected pathogens. Uni. J. Microbiol. Res., 2017; 5: 35-39.

17. Delcour A.H. Outer membrane permeability and 
antibiotic resistance. Biochim. Biophys. Acta., Proteins Proteomics, 2009; 1794: 808-816. https://doi. org/10.1016/j.bbapap.2008.11.005

18. Nazif, N.M. Phytoconstituents of Zizyphusspina-christi L. fruits and their antimicrobial activity. Food Chem., 2002; 76: 77-81. https://doi.org/10.1016/S03088146(01)00243-6

19. Ramaiya, S.D., Japar, S.B., Muta, H.Z. Assessment of total phenolic, antioxidant, and antibacterial activities of Passiflora species. Sci. World. J., 2014; 1-10. https:// doi.org/10.1155/2014/167309

20. Lopez-Vargas, J.H., Fernandez-Lopez, J., Perez-Alvarez, J.A., Viuda-Martos, M. Chemical, physico-chemical, technological, antibacterial and antioxidant properties of dietary fiber powder obtained from yellow passion fruit (Passiflora edulis var. flavicarpa) co products. Food Res. Int., 2013; 51: 756-763. https://doi.org/10.1016/j. foodres.2013.01.055

21. Onuh, J.O., Shiriki, D., Ubwa ,S.T., Shambe, T. Isolation of six microorganisms from rotten Dioscorea alata (water yam), and antimicrobial sensitivity test with nine plant extracts. Food Nutr. Sci., 2015; 6: 13811394. https://doi.org/10.4236/fns.2015.615144

22. Olakunle, O.M., Bola, A. GC-MS Analysis of phyto components from the stem bark of Cola nitida Schott \& Endl. J. Plant Sci., 2017; 5: $99-103$.

23. Li, L., Xuexiang, C., Weiwei, Z., Yunhao, W., Xiang, D., Lili, C., Dangquan, Z., Wanxi, P., Systematic characterization of volatile organic components and pyrolyzates from Camellia oleifera seed cake for developing high valueadded products. Arab J. Chem., 2018; 11: 802-814. https://doi.org/10.1016/j.arabjc.2017.12.031

24. Lalitharani, S., Ramasamy, V., Mohan, R.G.S. GC-MS analysis of ethanolic extract of Zanthoxylum rhetsa (roxb.) DC spines. J. Herb. Medi. and Toxicol., 2010; 4: 191-192.

25. Musthafa, K.S., Sahu, S.K., Ravi, A.V., Kathiresan, K. Antiquorum sensing potential of the mangrove Rhizophora annamalayana. World J. Microbiol. Biotechnol., 2013; 29: 1851-1858. https://doi.org/10.1007/s11274-0131347-8

26. Ahsan, T., Chen, J., Zhao, X., Irfan, M., Wu, Y. Extraction and identification of bioactive compounds (eicosane and dibutyl phthalate) produced by streptomyces strain kx852460 for the biological control of Rhizoctonia solani ag-3 strain kx852461 to control target spot disease in tobacco leaf. AMB Express, 2017; 7: 54. https://doi.org/10.1186/s13568-017-0351-z

27. Hassan, S.R., Zaman, N.Q., Dahlan, I. Influence of seed loads on start up of modified anaerobic hybrid baffled (MAHB) reactor treating recycled paper wastewater. Eng. Heritage J., 2017; 1: 5-9. https:// doi.org/10.26480/gwk.02.2017.05.09
28. De Assis Lage, T.C., Montanari, R.M., Fernandes, S.A., De Oliveira Monteiro, C.M., De Oliveira Souza Senra, T., Zeringota, V., Da Silva Matos, R., Daemon, E. Chemical composition and acaricidal activity of the essential oil of Baccharis dracunculifolia De Candole (1836) and its constituents nerolidol and limonene on larvae and engorged females of Rhipicephalus microplus (Acari: Ixodidae). Exp. Parasitol., 2015; 14: 824-29. https:// doi.org/10.1016/j.exppara.2014.10.011

29. Wasagu, R.S.U., Lawal, M., Amedu, A.M., Sabir, A.A., Kabir, S., Tukur, U.G., Zaharadeen, A. Comparative chemical analysis, phytochemical screening and antimicrobial activities of the rinds, seeds and juice of (Passiflora edulis var. flavicarpa) passion fruit. J. Nat. Sci. Res., 2016; 6: 138-143.

30. Zeraik, M.L., Yariwake, J.H. Quanti cation of isoorientin and total avonoids in Passiflora edulis fruit pulp by HPLC-UV/DAD. Microchem. J., 2010; 96: 86 -91. https://doi.org/10.1016/j.microc.2010.02.003

31. Dhawan K, Dhawan S, Sharma A. Passiflora: A review update. J. Ethnopharmacol., 2004; 94: 1-23. https:// doi.org/10.1016/j.jep.2004.02.023

32. Anibal, P.C., Peixoto, I.T.A., Foglio, M.A., Hofling, J.F. Antifungal activity of the ethanolic extracts of Punica granatum L. and evaluation of the morphological and structural modifications of its compounds upon the cells of Candida spp. Braz. J. Microbiol., 2013; 44: 839-848. https://doi.org/10.1590/S151783822013005000060

33. Aruldass, C.A., Marimuthu, M.M., Ramanathan, S., Mansoor, S.M., Murugaiyah, V. Effects of Mesua ferrea leaf and fruit extracts on growth and morphology of Staphylococcus aureus. Microsc. Microanal., 2013; 19: 254-260. https://doi.org/10.1017/ S1431927612013785

34. Tsuchiya, H., linuma, M. Reduction of membrane uidity by antibacterial sophora avanone $\mathrm{G}$ isolated from Sophora exigua. Phytomedicine., 2000; 7: 161-165. https://doi.org/10.1016/S0944-7113(00)80089-6

35. Plaper, A., Golob, M., Hafner, I., Oblak, M., Solmajer, T., Jerala, R. Characterization of quercetin binding site on DNA gyrase. Biochem. Biophys. Res. Commun., 2003; 306: 530-536. https://doi.org/10.1016/S0006291X(03)01006-4

36. Wu, D., Kong, Y., Han, C. et al. D-Alanine: D-alanine ligases as a new target for the flavonoids quercetin and apigenin. Int. J. Antimicrob. Agents, 2008; 32: 421-426. https://doi.org/10.1016/j.ijantimicag.2008.06.010

37. Chinnam, N., Dadi, P.K., Sabri, S.A., Ahmad, M., Kabir, M.A., Ahmad, Z. Dietary bio-flavonoids inhibit Escherichia coli ATP synthase in a differential manner. Int. J. Biol. Macromol., 2010; 46: 478-486. https://doi. org/10.1016/j.ijbiomac.2010.03.009 